following day (8 November) and saw the Barrow's Goldeneye and the Oldsquaw.

During the Christmas Bird Count on 31 of December, I saw a female Three-toed Woodpecker on the trunk of a spruce tree at Fort San. The bird was close, so the bar- red back and sides were clearly seen. This is the first record of this species for the Qu'Appelle Valley, although there are several records for Regina. It is an example of the many northern birds that have been pushed southward by this winter's extreme weather.

\title{
WINTER AVIAN ANOMALIES, RESTON, MANITOBA
}

\author{
DAVID L. BRADDELL, Box 304, Reston, Manitoba. ROM 1 X0
}

Reston is a village of approximately 600 people in Manitoba only $15 \mathrm{mi}$. (24 km) east of Saskatchewan and on PTH \#2, southwest of Virden, Manitoba. Because it has a welltreed, 4.5-acre park with clumps of spruce, pine and tamarack and many shrubs and other trees, a four-row shelterbelt on the west side, numerous evergreens on private lots, and several birdfeeders, Reston experiences visits from a few boreal and western species of birds that might otherwise bypass the village.

On 23 October $1984 \mathrm{Mr}$. and Mrs. William Phillips observed a pair of nuthatches that sharply drew the couple's attention. The birds seemed only half the size of the usually seen White-breasted Nuthatches. It was quickly apparent, too, that both birds displayed a blackish line through the eye and no white stripe above the eye, as on the Red-breasted Nuthatch. As well, the birds' heads were lighter in colour than that of the frequently observed White-breasted Nuthatch. Evidence plainly suggested these had to be Pygmy Nuthatches, typically found in southern B.C. pine woods.

Staying only one day on the Phillips lot, the "pygmies" foiled chances of Manitoba Rare Bird Alert Committee members observing this western pair of visitors. Interestingly enough, only two days previousIy near gale-force westerlies had crossed this area, possibly bearing the Pygmy Nuthatches through the Crowsnest Pass.

For two winters now a Buffadee has visited the same Phillips lot. Last year it arrived 4 November and remained in Reston until the second week of February, 1985. 
From the side - I had an excellent view of it on three occasions when it visited our kitchen window bird-feeders - the Buffadee looked much like a tiny flying bison, being a Black-capped Chickadee with a very pronounced hump above its curving back, hence the name Buffadee.

As the bird displayed no visible antenna, it seemed rnost unlikely to be a transistorimplanted chickadee. Larry Bidlake, Regional Field Biologist, Brandon, Manitoba, denied knowledge of any research being conducted with Blackcapped Chickaddes (pers. comm., 9 December 1984). Herb Copland, Curator of Ornithology, Manitoba Museum of Man and Nature, Winnipeg, echoed Bidlake's point but suggested the bird might have developed a subdermal tumor or cyst (pers. comm., 3 January 1985).

The buffadee appeared to be quite normal, except for its black hump, fraternizing with other chickadees and flying with no apparent hindrance from its dorsal bulge. The bird's occasional visit, however, was novel, even amusing, as the tiny, twolegged bison charged across one's view.

Another avian oddity, also a second year visitor, was Pegleg, a Ruffed Grouse. Since its first appearance in December 1983, Peg's right foot has been missing; it could only stump along on that side, yet manages well enough in trees or on the ground. What a grip the grouse must have in its left talons!

Pegleg lived on the Burt Pierce lot abutting on the west shelterbelt referred to earlier. The grouse sheltered in one of two tall, heavy-limbed spruces and foraged in two crabapple trees and a long, low lilac hedge at the front and side of the lot.

I spent some time one afternoon watching Peg limping along high snow as he pecked seeds and buds off the lilac hedge. Sympathetic interest and care had caused Peg to become quite tame, allowing Mr.
Pierce to approach within 3-4 feet of this game, one-footed Ruffed Grouse.

A third eccentric of the avian line-up at Reston was Scruffy, an uncommonly common Redpoll. One of around 40 redpolls, including about 10 Hoary Redpolls, that use birdfeeders in town, Scruffy lived up to his name in possessing a semi-scalped look, with remaining feathers constantly ruffled and unruly, like a backstreet brat's botched brush-cut.

How Scruffy acquired his - or her (let us not be unfeminist!) - scraggly pate is anybody's guess. Did this bird escape the attack of a Northern Shrike or a Screech Owl? Or was Scruffy a peculiarly lucky refugee from a starting snowblower in which the redpoll had sought shelter? The positively frowsy scantness of Scruffy's head feathers suggested the second hypothesis, improbable as it sounds. Nevertheless, this redpoll was healthily active, apparently none the worse for its encounter of the third kind.

More uncommon than eccentric were the four crossbills that dropped into Reston 6 March 1985. First seen by Gladys Mason at her birdfeeder on the east side of town were a rusty-reddish male, an immature male in blotchy plumage, and an olive-grey female White-winged Crossbill. Then on 9 March our kitchen window feeder tray was successively visited by a female Red Crossbill and a female White-winged Crossbill. By 10 March all four birds visited the William Phillips birdfeeder or foraged in nearby spruce trees.

Skilled and efficient as crossbills are in using their specialized bills to extract seeds from evergreen cones, these interesting and colorful birds are almost clumsy when trying to extract the meat from a small sunflower seed. I have seen a crossbill use, as a final resort, the chickadee's method of holding the seed under a talon but using its bill as a pick rather than a hammer. As the soldier said to Dr. Zhivago in the film, "Adapt or you fail." 